\title{
International Legal Regulation of Space Tourism
}

\author{
Irina Ryzhenko \\ Ph.D. in Law, Associate Professor, Kherson State University \\ (Kherson, Ukraine) \\ E-mail: Rigenko_Irina@ukr.net \\ https://orcid.org/0000-0002-9208-2132
}

\section{Olena Halahan}

\author{
Senior lecturer, Kherson State Maritime Academy (Kherson, Ukraine) \\ E-mail: olena halahan@ukr.net \\ https://orcid.org/0000-0001-8392-6965
}

\begin{abstract}
Ryzhenko, Irina, and Olena Halahan (2020) International Legal Regulation of Space Tourism. Advanced Space Law, Volume 5, 83-90. https://doi.org/10.29202/asl/2020/5/8
\end{abstract}

The article analyzes the state of legal regulation of the process of organization and implementation of space tourism, defines the features of its application and its place in modern international space law. The legal norms in the field of space travel and the legal bases of their organization were analyzed.

An attempt to analyze the legal status of persons taking part in space missions was made. The issue of the international legal personality of the participants of the space tourist service contract was investigated. Particular attention was paid to the legal status of space tourists. The content of the definition of "cosmonauts as messengers of humanity into space" was analyzed. The issues of the risks inherent in space tourism activities and the international legal liability of the parties to the space tourist services contract were considered. It has been stated that a space traveler has a certain amount of rights and obligations throughout the period, from the beginning of preparation to the journey and ending with the period after returning to Earth. An indicative list of space tourists' rights has been restated, and examples of their obligations and limitations in time and space have been provided. It was noted that the legal status of persons who have the status of space tourists, does not coincide with the status of professional astronauts, despite the fact that the first and second performing space travel. It is proved that the concept of "space tourist" is an integral part of the concept of "participant of space flight". The study found that space tourists have the opportunity to undertake space travel on the basis of a contract for space tourist services and solely on a commercial basis. It was stated that the activities to be conducted while the tourist is in space should be well planned and approved by a particular state body - the national space agency of the launching country. A specific condition for the participation of a space tourist in space flight is the process of its preparation and the passage of special selection, which includes checking personal, biographical, medical information about the person, physical and mental health status, command of the language of communication and so on.

(C) Ryzhenko, Irina, 2020

(C) Halahan, Olena, 2020 
The study develops the idea that to determine the concept of space tourist does not matter the period during which the specified person has already made or is just planning his space trip. The study concluded about the need for further improvement and development of the theory of space law, while taking into account modern space practices and results and experience, obtained during the implementation of contemporary space programs.

Keywords: space tourism, international space law, space flight participant, liability, space travel service contract, professional astronaut, International Space Station.

Received: January 27, 2020; accepted: February 17, 2020

\section{Introduction}

The tourism sector is an area of foreign economic activity that is quite actively developing. Issues of international legal regulation of tourism occupy a special place in their study.

The Law of Ukraine "On Tourism" of September 15, 1995, No. 324/95-VR defines the general legal, organizational, and socio-economic principles of the implementation of the state policy of Ukraine in the field of tourism. It aims at securing the rights of citizens to rest, enshrined in the Constitution of Ukraine, freedom of movement, health care, a safe and environmentally friendly environment, the satisfaction of spiritual needs, and other rights when traveling. It establishes the principles of rational use of tourism resources and regulates relations related to the organization and implementation of tourism in Ukraine. Article 1 of the Law states that tourism is the temporary departure of a person from a place of residence for wellness, cognitive, professional, business, or other purposes without carrying out paid activity in the place where the person goes.

Depending on the purpose of the tourism industry, different types of tourism are distinguished, including those for acquaintance, recreation, for business purposes, for participation in sporting events, as well as educational, scientific, pilgrimage and space.

Today, in the world of modern tourist services, there is a new, but quite promising direction called space tourism, which is considered to be the most expensive, but most exciting for tourists. Any valid international legal act does not prohibit space tourism. Space tourism is a type of commercial space activity.

Space tourism has already become a reality. The number of modern companies intending to provide space tourism services is steadily growing. The same can be said about their representatives. At the same time, with the increase of space tourism companies, it is possible to predict in the near future a decrease in the cost of these services, which in turn may lead to a wider involvement of the inhabitants of our planet in tourist journeys to space.

In all circumstances, such space law as space tourism will be further developed. Therefore, for their harmonious development, all their stakeholders and member states should develop unified rules of the game. In all circumstances, such space law as space tourism will be further developed. Therefore, for their harmonious development, all their stakeholders and member states should develop unified rules of the game. The study of space tourism issues and the prospects of their international legal regulation will remain a topical and vital problem for a long time.

The primary purpose of this study is to consider the concept of space tourism, to study in the international legal sphere the problems of improving its international legal regulation. 
The research should identify the main issues that exist in the context of international and national law and the prospects for their legal fixing.

Therefore, the legal regulation of space tourism is not well understood in the legal literature. Also, these issues are studied at the boundaries of international space and international tourism law, and therefore, when considering these issues should consider both the sources and existing principles and norms that determine the international legal regime for the organization of space tourism.

\section{Presentation of the main material}

In December 2004, a law was approved in the United States to legalize the use of private property for the purpose of space flight organizing.

In 2002 States Parties of the International Space Station program agreed on a document entitled "Principles Regarding Processes and Criteria for Selection, Assignment, Training and Certification of ISS," which set the general criteria for the selection of astronauts and visitors to the International Space Station (Gerold et al., 2013).

Roscosmos and Space Adventures have been cooperating in the area of organizing tourists' flights since 2001 .

In connection with the implementation of space tourist flights, there was a need for legal support for this activity. To create a regulatory framework, it is necessary to prepare a basic concepts and terminology. First of all, the meaning of the concept of space tourism should be defined.

From national laws governing the activities in the field of tourism, they regulate exclusively relations that arise within the framework of their national laws.

And space tourism is a type of tourism that is implemented in outer space, which studies the participation of the citizen in outer space. Therefore, space tourism cannot be governed by national laws on tourism.

Richard Crowther, in his work "The regulatory challenges of ensuring commercial human spaceflight safety," has defined the term "space tourism" as "the term commonly used to refer to ordinary members of the public buying tickets to travel to space and back" (Crowther, 2011).

Steven Freeland in his work "Up, Up and ... Back: The Emergence of Space Tourism and Its Impact on the International Law of Outer Space" defined the term "space tourism" as "any commercial activity offering customers direct or indirect experience with space travel" (Freeland, 2005).

The concept of space tourism can be combined with the observation of objects and phenomena in outer space during space flight with the help of both space and terrestrial infrastructure. The primary purpose of space tourism is the use of outer space.

Thus, it can be summarized that space tourism can be called paid for private account flight management services for one person or a group of people in space or in Earth orbit for the fulfillment of their scientific, research needs, or entertainment and cultural purposes.

Reflecting on activities in the field of space tourism, it will be interesting to characterize the range of services that can be provided to users. In this connection, we can find interesting the opinion of researcher Marina Krytkina, who suggests that space tourism may include "participation of citizens in a manned space flight as a passenger (crew member), observation of objects and phenomena in outer space, as from specially equipped places on Earth for this, and in the process of participating in a manned space flight; use of space infrastructure, as well 
as the monitoring of its functioning; use of decommissioned space technology, as well as the results of space activities for tourism" (Krytkina, 2015).

She was speaking about the commercial human spaceflight market Professor Crowther names such persons as "the operator, the flight participants, and third parties" who may be considered as the parties of the agreement of space tourism (Crowther, 2011).

Following the theory of international space law, space tourism can be understood to mean the following activities, such as the participation of citizens as space flight passengers, observing phenomena and objects in space when traveling through space or being in specially equipped places on Earth, application space infrastructure and observation of its activities, the use of special space technology. The concept of space tourism can also include activities such as visiting an observatory, observing the launching of space objects at a spaceport, using a special center and equipment to train astronauts, staying at a flight control center, and more.

\section{Determination of legal personality of the space tourist}

The Agreement on the rescue of astronauts, the return of astronauts, and the return of objects launched into outer space was considered and negotiated by the Legal Subcommittee from 1962 to 1967. Consensus agreement was reached in the General Assembly in 1967 (resolution 2345 (XXII)), and the Agreement entered into force in December 1968. The Agreement, elaborating on elements of articles 5 and 8 of the Outer Space Treaty, provides that States shall take all possible steps to rescue and assist astronauts in distress and promptly return them to the launching State, and that States shall, upon request, provide assistance to launching States in recovering space objects that return to Earth outside the territory of the Launching State (The Rescue Agreement, 1967).

The concept of "space tourist" is an integral part of the concept of "participant of space flight." It should be noted that the legal status of persons with the status of space tourists does not coincide with the status of professional astronauts, even though both the first and the second make space travel. Also, for the definition of the space tourist, the period during which these individuals have made their commercial space travel, or just going to implement it is not essential.

An individual - space tourism throughout the period, from the beginning of the preparation to the journey and ending with the return after returning to Earth, must have a certain amount of rights that it can exercise. In particular, a space tourist has the right to receive complete and reliable information about the rules of entry into and stay in space, to free access to tourist resources, to ensure personal security and preservation of his property, to receive medical aid, to compensation for losses and compensation for non-pecuniary damage in case of failure to fulfill the terms of the contract for space tourist services, etc. A space traveler must fulfill his obligations under the terms of the space travel agreement.

During space travel, preparation for transit, and transit, the space tourist must fulfill a number of obligations. In particular, he must adhere to international space laws and space rules, preserve the environment of outer space, and observe personal safety rules throughout the journey.

A special condition for the participation of a space tourist in space flight is the process of his preparation. In particular, the space tourist must pay the full cost of the flight. In case the specified person does not take part in the flight, not due to the fault of the organizing flight, then the expenses for space travel will not be refunded to the tourist. Due to the high cost of space travel services, the risks in this area should be insured from the outset. 
In order for an individual to be able to fly into space, he must undergo a very thorough selection, which includes the verification of personal, biographical, medical information about the person, the state of his physical and mental health, the level of command of the language of international communication, the absence of diseases that would endanger the life and health of the potential space tourist.

Particularly, the International Space Station medical community has adopted a document entitled "International Space Station Medical Standards and Certification for Space Flight Participants." It is emphasized that the criteria applied to the ISS spaceflight participant candidates are substantially less stringent than those for professional astronauts and/or crewmembers of visiting and long-duration missions to the ISS

\section{Legal grounds for space tourism}

One of the essential attributes that define space tourism activities is the conclusion of an agreement. The subjects of this contract are: a natural person - a space tourist and a representative of a company providing services in the field of space travel.

Activities that will be undertaken, while a tourist is in space, should be well planned and approved by a particular state body - the national space agency of the launching country.

Upon arrival of the space tourist back to Earth, his obligations to fulfill the terms of the contract are not terminated. Considering, that this person was with professional astronauts, who together with the tasks, provided by the terms of the space service agreement, at the same time fulfilling their functional responsibilities, and this person could be present during a series of experiments, accordingly, a space tourist may be subject to a number of restrictions on exporting information. Also, the space traveler must return the equipment used during the space trip.

The provisions of the first part of Article V of the Outer Space Treaty about the fact that all States Parties "regard astronauts as envoys of humanity to space." This phrase implies a legally complex content that would provide an opportunity to protect people involved in space exploration for the benefit of all mankind, because of fears of the United States of America and the former USSR that they are dealing with space travelers may not proceed correctly in the event of an unforeseen emergency landing within the jurisdiction of another country.

The same right of defense is provided for the category of persons designated as "envoys of mankind to space" in situations where they will also be in space that does not fall under the jurisdiction of any state but will need assistance. Article V of the Outer Space Treaty can be interpreted as imposing an obligation on those who may be concerned to provide information on space travelers (Cheng, 1997).

\section{Space excursions safety issues}

When we talk about the safety of space travel, the matter referred to the protection of falling just two categories, first spaceship crew and second space tourists. Throughout the space spacecraft, they will take part in a space trip, together with crew members they are considered space travelers who may be in trouble.

The desire to secure the possibility of protection for "space travelers in need" has always been a subject of study of international space law. The United Nations Committee on the Peaceful Uses of Outer Space (COPUOS) has been working on this issue. The idea of protecting space travelers has been reflected in several provisions of the UN General Assembly resolution 
1962 of 13 December 1963 entitled "Declaration of Legal Principles Governing the Activities of States in the Exploration and Use of Outer Space."

So in principle nine, it was stated that "States shall regard astronauts as envoys of mankind in outer space, and shall render to them all possible assistance in the event of accident, distress, or emergency landing on the territory of a foreign State or on the high seas. Astronauts who make such a landing shall be safely and promptly returned to the State of registry of their space vehicle".

As we can see, the 1962 resolution is quite rightly regarded as the starting point for the beginning of the drafting of the Space Treaty in the context of Article V.

The next important document - the 1967 Space Treaty uses the terms "astronauts," which sometimes creates some confusion due to the peculiarities of translating this document and the Russian side's desire to use the term "cosmonaut." Nevertheless, the Treaty's multilingual texts have the same legal force. Similar is the situation with the use of the term "taikonaut," which was used to name astronauts in Chinese.

At the time of preparing the provisions of the Space Treaty, the question of the possibility of participation in space travel by individuals was not considered, so there was no need for a precise definition of the term "astronaut." Therefore, it is believed that this term is more descriptive than technical, and may refer to any person traveling to space or traveling aboard a spacecraft.

However, in connection with the aboard of persons who are considered space tourists and who make their space travel on a commercial basis, it is advisable to ask how to call such space passengers, since the use of the term "cosmonaut" about them will give them the opportunity to acquire the rights and responsibilities of astronauts (Hobe et al., 2017) professionally.

In the following document - "Agreement on the Rescue of Astronauts, the Return of Astronauts and the Return of Objects Launched into Outer Space," the term "Spacecraft" is used instead of the term "astronaut."

In contrast to professional astronauts who, for professional reasons, take part in space missions, have many years of practice, and actually ensure the operation of spacecraft, "space flight participants" are tourists who have a commercial and private nature of travel and recreation. The term "space flight participant" was proposed by the participants of the International Space Station program in order to separate from each other the categories of persons flying into outer space. The separate category includes the scientists who conduct various experiments, and the main purpose of which stays aboard the space shuttle is the implementation of research activities.

The presence of a tourist component during a space flight hinders the activity of crew members, as space tourists distract crew members — professional astronauts who perform their functional duties.

Staying of the participants of a spaceflight on the spacecraft should be appropriately regulated. Thus, the amendments to the US Commercial Space Launch Act 2004 provided a detailed legal regime for commercial space flights and set licensing requirements for commercial space-operated space suites. In any case, a space flight participant will have only those powers that are characteristic of the space tourist. Still, they must in no way duplicate the rights and responsibilities of professionally trained astronaut personnel. The conditions in which space tourists will stay will be different from the usual requirements for ordinary tourism. They will remain in a closed environment for a long time, in the face of large temperature fluctuations and radiation levels. 
It should be noted that a member of the NASA program "Teacher in Space," an American teacher and astronaut from Concord, New Hampshire Sharon Christa McAuliffe, died in the wake of the Challenger spacecraft after its launch, belongs to the category "Space flight participant." Considering that the US National Aeronautics and Space Administration (NASA) applies the term "astronaut" to persons, who are the members of space crews, perform the functional duties of commander, pilot, flight specialist, flight engineer and were selected to serve NASA in order to be directed into the Earth's orbit and beyond, the Russian crew members perform the functional duties of the ship's commander and flight engineer, as well as being able to qualify as a test astronaut and a space astronaut. None of the categories of positions mentioned above may be replaced by the term "commercial flight attendant" because of the number of competencies that underlie them. There are also concepts such as "persons engaged in extra-ship activities under the program" and "other persons involved in any phase of the flight."

\section{Conclusions}

Despite the fact that very few people can afford space travel for themselves space tourism can be considered as a promising source for the future development of astronautics, its legal regulation will require a thorough study, that in the near future will become a subject of attention for scholars in the field of international law.

Although space flight makes a significant contribution to the development of science, they have a negative impact on the ozone layer, which can further lead to an environmental catastrophe on Earth. However, taking into account the desire of humans to fly into space and the ability of only a few of them to realize this idea into practice, we can talk about certain capabilities of organization of short, relatively cheap, but not tested suborbital flights. However, these activities should be regulated and solely supported by the state.

Today, there is no specific law on space tourism, but in the case of the spread of the phenomenon and the need to ensure its legal regulation, a relevant legislative act can be developed in the countries concerned with the introduction of information on the rights and responsibilities of tourism operators, similar to the sections of laws on tourism basics of tourism activities of these countries.

It should be noted that in order to develop and improve the legal regulation of the activities related to space tourism, it is necessary to continue research related to the study of systematization of the legal framework in the field of space tourism, the mode of stay of tourists, their rights and responsibilities, rights and responsibilities of the organization, which provides space flight services, flight conditions, safety issues and the quality of services received. Separate sections on the use of outer space for tourism purposes should be included in the state's new space laws. It is advisable to consider the issue of legal regulation of space tourism not from the position of the Law on Tourism, but the location of the Law on Space Activity.

\section{References}

A/RES 2345 (XXII) (1967) Agreement on the Rescue of Astronauts, the Return of Astronauts, and the Return of Objects Launched into Outer Space Adopted on December 12, 1967, Resolution 2345 by the UN General Assembly 22st Session, Proclaimed December 3, 1968. https://www.unoosa.org/pdf/gares/ARES_22_2345E.pdf 
A/RES/1962 (XVIII) (1963) Declaration of Legal Principles Governing the Activities of States in the Exploration and Use of Outer Space Adopted at the $1280^{\text {th }}$ plenary meeting, 13 Dec. 1963. http://digitallibrary.un.org/record/203965/files/A_RES_1962\%28XVIII\%29AR.pdf

Agreement on the Rescue of Astronauts, the Return of Astronauts and the Return of Objects Launched into Outer Space (1967) (RES 2345 (XXII)). https://www.unoosa.org/oosa/ en/ourwork/spacelaw/treaties/ rescueagreement.html

Cheng, Bin (1997) Studies in International Space Law, Clarendon Press, Oxford. https://orcid. org/10.1093/acprof:oso/9780198257301.001.0001

Crowther, Richard (2011) The regulatory challenges of ensuring commercial human spaceflight safety. Space Policy. Vol. 27, Issue 2, pp. 74-76.

Freeland, Steven (2005) "Up, Up, and ... Back: The Emergence of Space Tourism and Its Impact on the International Law of Outer Space", Chicago Journal of International Law: Vol. 6: No. 1, Article 4. https://chicagounbound.uchicago.edu/cjil/vol6/iss1/4

Gerold, Gerhard, Michael Fremerey, and Edi Guhardja (2013) Land Use, Nature Conservation, and the Stability of Rainforest Margins in Southeast Asia. Springer Science \& Business Media, p.51

Hobe, Stephan, Bernhard Schmidt-Tedd, Kai-Uwe Schrogl, Rada Popova, and Martin Reynders (2017) Cologne Commentary on Space Law — Outer Space Treaty. BWV Berliner Wissenscafts-Verlag.

Krytkina, Marina (2015) Legal Regime of Space Tourism. Aktual'nyye problemy aviatsii $i$ kosmonavtiki, Vol. 2, p. 457. 